\title{
Constitutively, pathologically, profoundly
}

There are a hundred reasons to love the JCI and I have loved it truly, madly, and deeply for the last nine years. Alas, I'll have to learn to love the Journal from afar, as tomorrow marks my last official day as Executive Editor. To quote Chaucer, "There is an end to everything, to good things as well."

Dearest JCI, how do I love thee? Let me count the ways. I love that our readers can actually believe what we print: we maintain standards of the highest integrity during the evaluation phase, and all our figures are checked thoroughly once accepted. I love that the JCI is unique in bringing together (physically, once a week) a dedicated group of practicing scientists who have a deep understanding of the actual science and an ability to parse through referee reports. I love that the metric we have used for evaluating papers isn't based on the terms hot or sexy, but rather on actual clinical, therapeutic, and mechanistic merit. I love that the potential effect on our impact factor has never been the driving force for the consideration of a manuscript. But mostly, I love this Journal for the people who have made this the best job in biomedical science.

I was a young manuscript editor at Nature Medicine when I met Andy Marks (JCI Editor in Chief, 2002-2007) at a 2003 Keystone meeting. He thought I was a postdoc for half our dinner with mutual colleagues, but happily, I

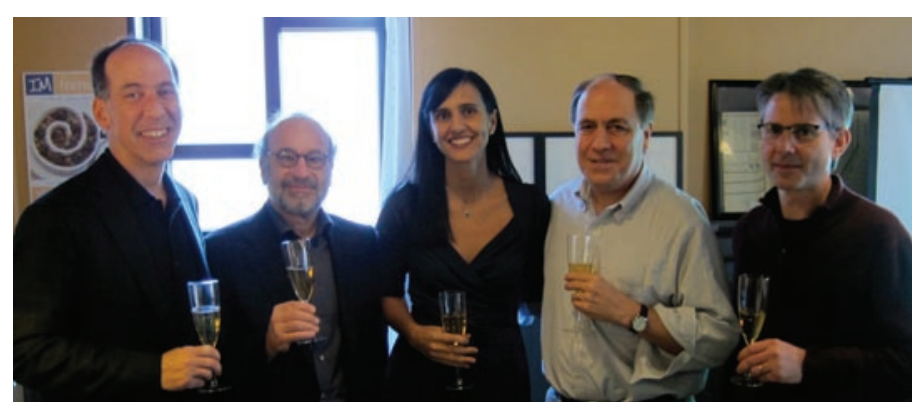

Figure 1 Together with Penn editors Larry Turka, Morrie Birnbaum, Gary Koretzky, and Jon Epstein. we were as fair as we could be to authors. He's kept the editorial board meetings running with thoughtful analyses of manuscripts far outside his field and has brought a levity and humor to the table that helps keep things enjoyable. He's a tremendously funny and easy person to work with. Beyond the daily delight of working with Larry, the board of Deputy and Associate Editors at Penn have become like family (Figure 1), and I will truly miss seeing them regularly after our last meeting at the end of this month.

One of the ways the Journal reinvigorates its content is by moving every five years,

hands - both on the editorial side and with the staff of JCI's Ann Arbor-based production office, who are worthy of every superlative in the English language - especially the brilliant John Hawley and Karen Guth. I also want to recognize the incredibly skilled professional editors I've been blessed to have worked beside (Brooke Grindlinger, Laurie Goodman, Stacie Bloom, Karen Honey, Kathryn Claiborn, and Sarah Jackson).

I'm also sad that I won't be able to see so many of you so often. These nine years have given me the chance to see the world and meet a diverse group of scientists - many of whom have become close friends. Many have sent inappropriate e-mails (among the most unforgettable: "Are you wearing a bra?"; "It is a shame I am old enough to be your Dad [I would have been 17 at hypothetical conception] or I would give your husband a run for his money"; "If your sweetheart ever turns sour, we should elope"). Many - not necessarily friends - have sent inappropriate e-mails of another, angrier sort ("You are the evil seed"; "Seriously, my three year old could make a better decision than you"; "Your actions remind us about the Stalin era in Russia and the McCarthy era in your country" tie for most memorable, followed by exhortations that I needed a spanking from two different authors). And still other friends have been subjects of my more made a good enough impression that two weeks after the

conference, I was interviewing for this position. Working with Andy for four of the five years when the JCI was based at Columbia was a dream - those of you who know Andy or have read his articles and editorials know that Andy is a man of conviction who sees a problem and fixes it. He is a born leader and was an effective Editor in Chief; the JCI thrived under his watch, and while I'd like to take credit for that, it is because Andy and I worked well as a team, together with the fantastic and dedicated Columbia Universitybased editorial board he brought together.

When the JCI moved to the University of Pennsylvania in 2007, Larry Turka took over as Editor in Chief. Larry's leadership style was different - more consensus building and measured decisions; he transformed the way we handled manuscripts to make sure that

and following this tradition, Howard Rockman (Duke University) took over the reins on March 1 of this year. Unfortunately for me, this unique way of running the Journal has provided a logistical hurdle in that I was finding it difficult to commute weekly to Durham from my base in NYC. Chief among my regrets about leaving this position is that I won't get the chance to synergize with Howard in the same way that I developed close working friendships with both Andy and Larry. Howard has proven himself so far to be a gifted leader with a sharp intellect and a ready laugh. I think all authors and readers will find he's going to be an excellent steward - with his merry band of Editors from Duke and UNC-Chapel Hill to help him. It reassures me greatly to know that I leave the JCI in such capable recent predilection to turn embarrassing photos into fake JCI covers (some of you should be glad I do not have a blog). Regardless, it is my great hope to keep up the friendships I've made over these years.

Happily, I'll be staying on at the JCI as an Editor at Large, since I can't quite cut the cord completely. My next position as Director of the Office of the President of Memorial Sloan-Kettering Cancer Center will also keep me involved in biomedical science and policy. And those of you who have known me to be tenacious as a editor will find that I will be equally tenacious as a friend - you'll not see the back of me just yet.

\section{Ushma S. Neill, Executive Editor/ Editor at Large}

